DOI:https://doi.org/10.4796o/2303-7431.25.2021.87

UDK: $316.774: 316.32$

Pregledni članak

Primljen 7. II. 2021.

Prihvaćen 6. XII. 2021.

IVANA RAŠAN

Sveučilište u Zagrebu, Fakultet elektrotehnike i računarstva

ivana.rasan@fer.hr

\title{
MEDIJSKA KULTURA DANAŠNJICE I NAMETNUTE ŽIVOTNE VRIJEDNOSTI
}

\section{Sažetak}

U radu se daje osvrt na moderno društvo i popularnu kulturu kao kulturu nametnutih vrijednosti, utjecaje koji proizlaze iz iste te načine na koje funkcionira današnje društvo koje živi u svojevrsnoj medijskoj šumi. Također, bit će riječi i o tome kako društvo funkcionira u neograničenoj slobodi izbora te kako se promatra sustav vrijednosti današnjice i utjecaji proizašli iz konzumiranih medijskih sadržaja. U središtu svega promatra se čovjek i postavlja se pitanje je li on u današnjoj informacijskoj šumi sposoban smoći snage za dubinsko razmatranje informacija koje su predstavljene radi različitih manipulativnih učinaka i odvajanja istih od onih informacija koje su kao takve distribuirane radi doslovnoga informiranja. U radu se zastupa ideja današnjega modernog društva koje, s jedne strane, živi „punim plućima“ u dostupnosti svega i okruženo svima, dok se, s druge strane, suočava s izolacijom i samoćom.

Ključne riječi: moderno društvo; mediji; čovjek; nametnute vrijednosti; framing 


\section{Uvod}

Kada bi se neku osobu neposredno nakon davne 1455. godine, točnije nakon što je Gutenberg tiskao prve primjerke Biblije u njemačkome gradu Mainzu', upitalo smatra li da će navedena pojava imati neopisivo jak utjecaj u kontekstu pokretanja reformi, narušavanja moći crkve, stvaranja novih društvenih klasa i zanimanja, odgovor bi vrlo vjerojatno bio negativan. Vjerojatno bi se i 6o-ih godina prošloga stoljeća izazvalo čuđenje kada bi se ljude upitalo misle li da će u skoroj budućnosti moći komunicirati putem umreženih ekrana, da će jednim stiskom nekoga gumba moći dobiti informacije o apsolutno svemu i o apsolutno svim događanjima u bilo kojem dijelu svijeta. Pri tome, ovaj se dio ne odnosi na razmatranje točnosti tih u budućnosti dostupnih informacija, nego samo na postojanje mogućnosti za takav način funkcioniranja svijeta.

Nemogućnost poimanja otvaranja prostora za ogromne promjene $\mathrm{u}$ kojima se, može ga se tako slikovito nazvati, nespreman čovjek našao, dovodi do toga da, tako nespreman, kao spužva upija nametnute sadržaje, ali nije sposoban odvajati važne od nevažnih, a kamoli promišljati na nekim višim razinama o istinitosti predstavljenih informacija kao ni o ciljevima onih koji ih predstavljaju. Ako se uzme u obzir da je percepcija rezultat složenih procesa koji su samo u djelomičnu obliku dostupni pojedinčevoj svijesti, što se zorno može opisati na primjeru kazališne predstave prilikom koje osoba koja sjedi u gledalištu percipira predsta$\mathrm{vu}$, ali ne percipira glumce iza zastora koji se presvlače i pripremaju u zadnji tren za sljedeću scenu, ne percipira šaptača, osobu koja brine o rasvjeti itd., vidljivo je da čovjek percipira samo segmente cjelokupne priče koja se zapravo oko njega događa. ${ }^{2}$ No, što bi se dogodilo u slučaju da šaptač skoči na pozornicu, da padne zastor iza kojega se drugi glumac presvlači, da osoba koja brine o rasvjeti upali sva svjetla i dođe na pozornicu dok se predstava i dalje igra? Ljudi u gledalištu percipirali bi

Usp. John Naughton, Od Gutenberga do Zuckerberga, Edicije Božićević, Zagreb, 2014., str. 11.

2 Usp. Ida Kolarek - Marin Milković - Tomislav Kosić, „Dizajn i vizualni efekti koji induciraju iluziju kretanja“Tehnički glasnik, Sveučilište Sjever, Varaždin, god. V. (2011.) br. 2., str. 81. 
sve te nove elemente, ali bi bili iznenađeni, zbunjeni i ne bi im bilo jasno što se zapravo događa. Mogli bi si postavljati pitanja je li to dio predstave ili je pak nastao kaos zbog loše organizacije, možda bi samo sjedili u čudu i promatrali, a da ništa ne upitaju. No, u svakome slučaju ne bi mogli imati jasnu sliku o tome što se zapravo događa. Upravo se na ovome slikovitom primjeru može objasniti i medijska šuma u kojoj se današnji čovjek nalazi. To bi značilo da su ljudi u velikoj većini postali bića koja u elementu iznenađenja očito percipiraju ogromne količine informacija, ali bez mogućnosti poimanja jasne slike o tome što se zapravo događa i koja je svrha svih serviranih informacija. Naughton ističe da su „arhitekti mreže uspješno stvorili globalni stroj za nizanje iznenađenja“" Uzme li se u obzir da je čovjek okarakteriziran u dvjema sferama, odnosno zaseban u fizičkome i zaseban u duhovnome, da se fizičkim smatra ono što čovjek okom može vidjeti i sluhom čuti te povuče li se paralela s tehnikama propagande koje podrazumijevaju da je propaganda danas u demokraciji ono što je batina bila u totalitarnoj državi ${ }^{4}$, on kao takav postaje savršeno biće koje je spremno prihvatiti medijski predstavljenu kreaciju stvarnosti. Stupanjem Gutenberga na scenu i razvojem tiskovina, pa pojavom univerzalnih poštanskih usluga koje su poboljšale cirkulaciju javne i privatne komunikacije, zatim pojavom brzojava (1843.), koji je Tom Standage prozvao „viktorijanskim Internetom“, stupanjem na scenu telefona (1876.) i gramofona (1877.), širenjem pismenosti (posljednjih godina devetnaestoga stoljeća), pojavom prvih "popularnih“ novina, točnije onih u masovnome opticaju, dolaskom kina i radiotelevizijskih medija (radio, 1920., televizija, kasne 1940.) ${ }^{5}$, slikovito se može reći da se život čovjeka u svim tim „olakšavajućim“ faktorima zapravo sve više komplicirao i postajao složeniji. Možda na prvu ne izgleda tako, ali činjenica je da mediji danas sve više određuju glavni put civilizacije društva. ${ }^{6}$

\footnotetext{
J. NAughton, $n . d j$., str. 4.

4 Usp. Noam Chомsкy, Mediji, propaganda i sistem, Što čitaš?, Zagreb, 2002., str. 111. Usp. J. Naughton, $n$. dj., str. 135.

6 Usp. Thomas A. Bauer, Mediji za otvoreno društvo, Sveučilišna knjižara d.o.o., Zagreb, 2007., str. 11.
} 


\section{1. Čovjek modernoga društva i nametnute vrijednosti}

Danas čovjek funkcionira u okružju dostupnosti svega, ponajprije dostupnosti informacija koje se šire vrlo jednostavno i iznimnom brzinom. Stvorile su se navike koje impliciraju nužnost dostupnosti svih informacija jednim klikom, a izgubilo se vrijeme potrebno za promišljanje, povezivanje i propitivanje istinitosti svih tih informacija, osobito za poimanje njihove svrhovitosti. Ljudi su počeli funkcionirati u okružju u kojem ne uviđaju moć tehnika manipulacija koje su proizišle iz silne dostupnosti sredstava preko kojih se komunicira. Manipulacija se više ne svodi samo na područje reklame ili politike ${ }^{7}$ nego se čovjek nalazi u okružju koje se svodi na neprestano unošenje neosviještena uplitanja medija u međuljudske odnose svakodnevice. Ljudi uglavnom žive u demokraciji koja promiče slobodu u svim segmentima, a zapravo se javlja svojevrsna zarobljenost $u$ kontekstu nužne izvrsnosti u svim životnim segmentima, koja dovodi do stvaranja (iz)manipulirana društva u kojem se pojavljuju razni oblici modernih bolesti (stres, nesanica, nervoza, anksioznost, depresija), kojima se teško dokučuje konkretan uzrok.

Čitav se život vrlo razvijenih društava predstavlja kao golema nakupina znakova zadovoljstva i sreće. Od izloga što blješte robom do reklama ozarenih smiješkom, od sunčanih plaža do tijela iz snova, od praznika do medijske razonode, posvuda se uzdižu katedrale posvećene predmetima i dokolici ... sve se prodaje kao obećanje naslade. U tom vrtu užitaka ugoda je postala bogom, potrošnja njegovim hramom, tijelo svetom knjigom. ${ }^{8}$

Sve navedeno može se reći pod okriljem popularne kulture koja postaje svojevrsni temelj suvremene kulture. ${ }^{9}$ Zapadno medijsko društvo koje u svojim sadržajima zastupa popularne izričaje povezane sa svim životnim segmentima postaje u jednome i potrošač i proizvođač takve vrste kulture, pri čemu i u procesu stvaranja, ali i konzumiranja takvih

Usp. Sead Alić, Mediji, od zavodenja do manipuliranja, AGM, Zagreb, 20o9., str. 116.

8 Gilles Lipovetsky, Paradoksalna sreća - ogled o hiperpotrošačkom društvu, Izdanja Antibarbarus, Zagreb, 2008., str. 97.

9 Usp. Danıjel Labaš - Maja Mihovilović, „Masovni mediji i semiotika popularne kulture“, Kroatologija, Hrvatski studiji Sveučilišta u Zagrebu, Zagreb, god. II. (2011.) br. 1., str. 95. 
sadržaja pronalazi zadovoljstvo. ${ }^{10}$ Upravo se navedene vrijednosti i nužnost izvrsnosti i individue promiču putem raznih medijskih sadržaja, a reklamni sadržaji za gotovo bilo koji proizvod ne odstupaju od imaginacije savršenstva. Na primjer, reklama za kavu koja upućuje na nužno postizanje sreće prikazivanjem dotjerane žene koja hoda kroz segmente svoga života s lakoćom dok se iza nje prikazuju predivne slike svih njezinih (zadanih) postignuća. ${ }^{11}$ Dok ona prolazi kroz život, doslovno se diktiraju zadane radnje koje se nameću većini žena danas, a to su: „zaljubi se, vjenčaj se, imaj predivnu djecu, kupi kuću, napravi od nje dom, budi ponosna, vidi svijet, slijedi svoje strasti, budi privlačna, izgubi na kilaži, nemoj izgubiti sebe, teži perfekcionizmu, budi snažna, ostani ženstvena, marljivo radi, napravi sve... ${ }^{12}$, da bi se na kraju reklame reklo: „Stani! Uzmi vremena da pronađeš vrijeme... ${ }^{{ }^{13}}$ za popiti kavu koja će razbistriti um i uz koju sve to počinje i moguće je postići. ${ }^{14} \mathrm{~S}$ jedne strane ukazuje se na cijeli niz savršenih radnji i postignuća, dok se s druge ipak ukazuje na potreban odmor, ali radi čega? Radi istinskoga odmora ili radi odmora za ispijanje kave koja će razbistriti um i pomoći da se dalje nastavi s postizanjem zadovoljenja svih savršeno prikazanih slika? Tako nametnuta savršenost može itekako negativno utjecati na niz ženskih osoba koje upijaju taj reklamni sadržaj zbog nerealna prikaza svih savršenih slika u pozadini zadanih životnih ciljeva koji se danas nameću kao imperativ. Razmotri li se malo dublje sve opisano, postavlja se pitanje: $\mathrm{Ne}$ bi li stvaran prikaz svih tih postignuća trebale u pozadini slijediti slike iscrpljene žene, ispijenih šalica kave, dok sjedi za stolom i radi, nervozne žene okružene građevinskim radnicima koji kasne s izvedbom planiranih radova za njezin savršeni dom, nenasmijane djece i supruga dok te žene nema jer boravi prekovremeno na poslu kako bi mogla financirati sve to i sl.? U slučaju stvarne inačice prikaza pozadinskoga sadržaja može se pretpostaviti da bi se upravo u tome sadržaju mogle prepoznati

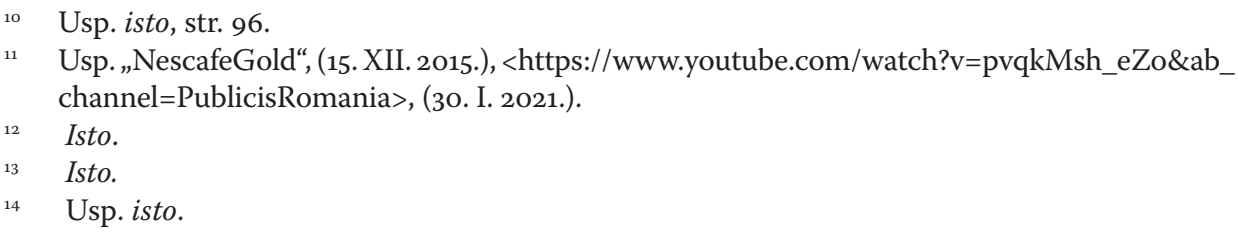

${ }^{11}$ Usp. „NescafeGold“, (15. XII. 2015.), <https://www.youtube.com/watch?v=pvqkMsh_eZo\&ab_ channel=PublicisRomania $>$, (30. I. 2021.).

Isto.

Isto.

Usp. isto. 
brojne žene te se postavlja pitanje: Zašto su pozadinske slike tako nerealne? Može se zaključiti da je tako upravo zato što je savršenstvo u svakome životnom segmentu nametnuto kao zadano, iako ga je, zdravorazumskim poimanjem, gotovo nemoguće postići u svim životnim segmentima i upravo se sadržaje slična tipa, koji okružuju današnje moderno društvo, može prepoznati kao nešto što stvara nemir i tjeskobu u cijelome društvu jer mu kontinuirano nameće nešto što je neprirodno i gotovo nedostižno.

\section{Kultura medijskoga društva - framing „prihvatljivosti“ svega}

McLuhan u svojim teorijskim promišljanjima iznosi kako su tijekom povijesti sva društva bila izložena ključnim medijima kojima su njegovi članovi komunicirali, odnosno više oblikovana prirodom medija od samoga sadržaja komunikacije, te definira četiri ključna razdoblja u kojima su ljudskom komunikacijom dominirali različiti mediji, a u tome kontekstu i različita osjetila. ${ }^{15}$ Tako je definirano (1.) plemensko doba u kojem je ključni komunikacijski alat bio govor, osjetilo sluh, a uz to bili su prisutni još i dodir, okus i miris. Izgovorena riječ djelovala je povezujuće te je stvarala osjećaje prisnosti i aktualnosti. Kasnije dolazi do (2.) izuma pisma te dominira vid kao sredstvo jer pismo kao takvo dovodi do individualizacije s obzirom na činjenicu da komunikacija postaje odvojena od komunikatora te da se navedeni ne moraju sresti ni vidjeti. Ključni oblik organizacije postaje linija te se u društvo uvode slijed, red, logika i razum. ${ }^{16}$ Nastavlja se dominacija oka s (3.) dobom tiska, ali dolazi do mehanizacije pisanja i pojavljivanja velika broja istovjetnih kopija te se stvara istovjetnost tipografskih elemenata, iz koje proizlazi homogenizacija društva i dolazi do pojave nacionalizma. Tisak kao takav potiče širenje znanja i informacija, kasnije će biti zaslužan za izazivanje industrijske revolucije, ali uz sve to stvara i otuđenost pojedinaca

${ }_{15}$ Usp. Darijo ČerepinKo, Komunikologija: Kratki pregled najvažnijih pojmova, teorija $i$ principa, Veleučilište u Varaždinu, Varaždin, 2011., str. 135.

16 Usp. isto. 
te potiče izolaciju. ${ }^{17}$ Trenutačna i neprekidna komunikacija javlja se (4.) izumom električne energije i medija koji su temeljeni na platformi, što izaziva povezanost svih, a što zapravo vraća u situaciju plemenskoga sela. Sluh kao komunikacijski alat ponovo dobiva na važnosti te se s njim vraćaju i ostale karakteristike plemenskoga doba koje pojavom električne energije postaju globalne. Mediji doslovno postaju produžetak ljudskoga živčanog sustava. ${ }^{18}$ Teorija medija, odnosno javnoga komuniciranja omogućuje povezivanje trostruke strukture povezanih društvenih praksi, točnije značenje, moć i proizvodnju. ${ }^{19}$ Značenje kao tumačenje određenih semioloških elemenata, moć koja proizlazi iz svih medijskih kanala današnjice (jasno je vidljiva kroz poistovjećivanje recipijenata $s$ nametnutim porukama koje iz tih kanala proizlaze) te proizvodnja koja, osim obilja mogućnosti, podrazumijeva i proizvodnju željenih emocija recipijenata. S obzirom na navedeno moguće je postaviti pitanje: Postoji li uopće mogućnost za definiranjem vlastitoga prostora iz kojega bi proizlazile vlastite kreacije i stavovi pojedinaca na koje neće utjecati elementi proizišli iz medijske šume raznih sadržaja?

Vrlo je zanimljiva priča o grčkome Narcisu koji je svoj odraz u vodi zamijenio s drugom osobom te mu je taj njegov „produžetak“ toliko otupio osjete da je postao servomehanizam vlastitoga produženog ili ponovljenog lika. ${ }^{20}$ Kako McLuhan objašnjava, ${ }^{21}$ smisao toga mita očituje se u činjenici da ljude odmah zadivi svaki njihov produžetak u svakome materijalu koji nije njihov dio. Greška koja se očituje u tumačenju Narcisa, a koja se javlja u današnjoj tehnološkoj (narkotičkoj) kulturi, može se prepoznati u tome što se vodi time da se Narcis zaljubio u samoga sebe, a zapravo je ispravno to da je bio opčinjen svojim produžetkom. U skladu s psihološkim tumačenjima („medicinski istražitelji, poput Hansa Selyea i Adolphea Jonasa, smatraju da svi naši produžeci, dok

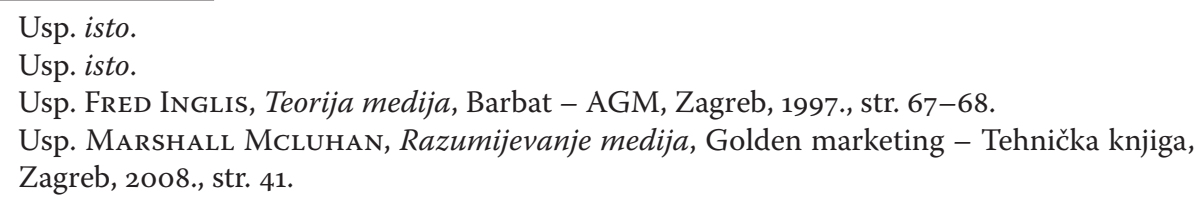


smo bolesni ili zdravi, predstavljaju pokušaje da održimo ravnotežu“" ${ }^{\text {(22) }}$ moguće je potvrditi kako nas neki naši produžeci dovode do stanja otupljenosti, a baš se tako može tumačiti priča o Narcisu, točnije kao samoamputacija ili produžetak izazvan podražajnim pritiscima koji zapravo sprječavaju samoprepoznavanje. ${ }^{23}$ Bitno je naglasiti da šok kao takav, bilo da je izazvan fizičkim ili psihičkim podražajem, izaziva odvajanje od samoga sebe, odnosno samoamputaciju, otupljenost ili pak povisuje prag za sve vrste percepcije. U skladu s Blakeovim poimanjem fragmentacije čovjeka njegovim tehnologijama ${ }^{24}$ moguće je povući paralelu s današnjim „raspadnutim“, segmentiranim i rastrganim čovjekom koji više nije u stanju procijeniti je li ono što on želi zaista njegova želja ili je riječ o anticipiranim željama koje su mu nametnute putem svih danas dostupnih medijskih izvora (npr. reklamni sadržaji koji ističu nužno savršenstvo u bilo kojemu segmentu, savršena putovanja, lijekovi za savršeno raspoloženje, savršen izgled itd.). Činjenica kako je u nekim situacijama nužno proizvesti otupljenost živčanoga sustava (kada je središnji živčani sustav produžen i izložen, potrebno ga je otupjeti kako ne bi nastupila smrt) ${ }^{25}$ može dovesti do zaključka da je danas, slikovito rečeno, potrebno posjedovati dozu otupljenosti kako bi čovjek uspio preživjeti zatrpanost informacijama i serviranim sadržajima. S druge strane, treba se propitivati postoji li danas uopće prostor za oblik „zdrave“ zatupljenosti čija je svrha zaštititi samoga sebe i uživati u doslovnoj slobodi izbora i iznošenja vlastitih stavova ili je u većini slučajeva moguća samo ona doslovna zatupljenost izazvana prevelikom količinom informacija koju čovjek jednostavno nije u mogućnosti svrsishodno konzumirati te ga ista zapravo koči u naumu da bude slobodan u kontekstu mogućih vlastitih odabira i priklanja se odabiru slaganja sa svime što je masovno nametnuto.

„Danas je, manje-više, moguće o svemu govoriti i pisati, pa ipak su rezultati te 'slobode' i više nego skromni. ${ }^{{ }^{26}}$ Kultura slobode i demokracije

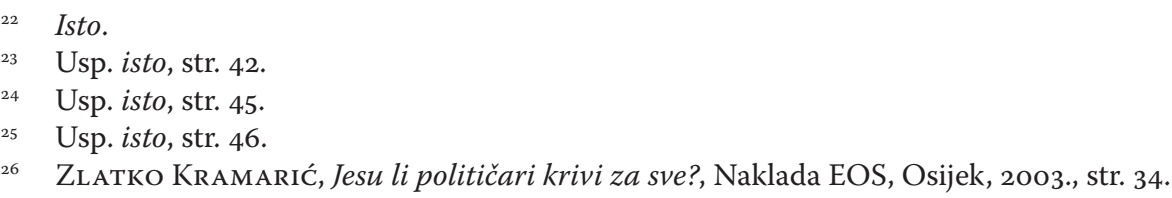


danas očito ne funkcionira u skladu s doslovnim značenjem navedenih riječi, nego samo prividno. Njemačka znanstvenica Noelle Neumann „spiralom šutnje“ definira mehanizam koji podrazumijeva odabir šutnje pri iznošenju stavova ako čovjek zaključi da se njegovi stavovi bitno razlikuju od mase. ${ }^{27}$ Neumann tvrdi da postoje samo dva tipa individualaca koji će iznijeti vlastite stavove ako se isti i razlikuju od mišljenja mase, odnosno javnoga mnijenja, a to su "hard core nekonformisti“ i „avangarda“. Tvrdi da se navedeni ne boje iznijeti vlastite stavove jer ih je javnost ionako već odbacila i nemaju više što izgubiti, a s druge strane drže ih njihova uvjerenja da su zapravo ispred svoga vremena. Ako je u današnjoj demokraciji i slobodi govora prisutna „spirala šutnje“, u kojoj je mjeri onda ta sloboda koja se danas toliko uzvisuje i naglašava zapravo prisutna i postoji li ona ili je to sve samo proizvod framinga? Framing se kao koncept prvi put pojavio u socijalnoj psihologiji (psiholozi su tada izraz frame koristili kako bi opisali načine na koji ljudi uključuju, isključuju i organiziraju iskustvo) sedamdesetih godina, kada ga Erving Goffman (1974.) spominje u svojoj knjizi Frame Analysis ${ }^{28}$ u kojoj govori o društvenome međudjelovanju koje se odvija kao igra po određenim prihvaćenim pravilima. ${ }^{29} \mathrm{U}$ navedenoj knjizi Goffman iznosi činjenicu kako svi mi, kako bismo pronašli smisao, klasificiramo, organiziramo i interpretiramo vlastita iskustva. ${ }^{30}$ Goffman u navedenome djelu suočava socijalnu interakciju i povezanost s interpretacijskim okvirima. Framing koncept podrazumijeva teoretski koncept koji se bavi novinarskim odabirom vijesti i pri tome pokušava objasniti i njihovu stabilnost i njihove promjene..$^{31} \mathrm{U}$ novijim istraživanjima pojmovi „okvira“ $\mathrm{i}$ „uokvirivanja" usmjereni su na razotkrivanje načina na koje novinarske priče

${ }_{27}$ Usp. D. ČEREPINKo, $n$. dj., str. 164.

28 Usp. Erving Goffman, Frame analysis: An essay on the organization of experience, Harper \& Row, New York, 1974.

29 Usp. VedAda BARAKovic, „Medijska konstrukcija ekstremnog vremena: Ključne riječi i metafore kao alati framinga", Medijski dijalozi, časopis za istraživanje medija i društva, Istraživački medijski centar - Podgorica, Podgorica, god. V. (2012.) br. 13. - 14., str. 507.

3o Usp. E. Goffman, $n$. dj., str. 21.

${ }_{31}$ Usp. Michael KuncziK - Astrid Zipfel, Uvod u znanost o medijima i komunikologiju, Zaklada Fridrich Ebert, Zagreb, 2006., str. 147. 
funkcioniraju kao takve. ${ }^{32}$ Vijesti podrazumijevaju destilirani oblik višestrukih događaja koje mediji odabiru, smisleno strukturiraju te ih smještaju unutar određene priče kako bi ih učinili važnima za recipijente. ${ }^{33}$ Moguće je razlikovati četiri mjesta na kojima frames zadiru u proces odabira vijesti, odnosno: koja su to zbivanja koja će novinari shvatiti kao događaj, zatim koji će aspekti nekoga događaja biti odabrani za izvješćivanje, u koji će se tematski kontekst određeni događaj smjestiti te kako će se odrediti vrijednost vijesti događaja. ${ }^{34} \mathrm{U}$ skladu s navedenim može se zaključiti da su zapravo svi društvu dostupni sadržaji već unaprijed omeđeni načinom na koji će ih recipijenti/društvo percipirati, a uz to su već unaprijed određene i emocije koje bi ti sadržaji trebali masovno proizvesti. Prema tomu, ranije spomenuta zdrava otupljenost može se promatrati kao nužni štit svakoga pojedinca, štit koji će mu omogućiti produkciju vlastitih doživljaja, emocija i mišljenja.

\section{Sloboda izbora ili medijski produciran totalitarizam}

Lippman tumači doživljaje vanjskoga svijeta koje ne bismo bili u mogućnosti vidjeti, dotaknuti ili čuti kao pseudostvarnost koja je zapravo samo slika stvarne stvarnosti i niz doživljaja koje pojedinac percipira i osjeća na temelju informacija koje dobiva preko ključnoga kanala kroz koji iste dolaze, a to su masovni mediji koji zapravo oblikuju slike u našim glavama. ${ }^{35}$ Današnje umreženo društvo, obavijeno masom medijskih sadržaja, s jedne strane potiče neprestanu komunikaciju putem društvenih mreža, dok s druge strane kreira osamljena pojedinca. S jedne strane promiče se neograničena sloboda, dok se s druge strane itekako živi u skladu s nametnutim pravilima i umjetno kreiranim željama. „Stado je tako vitalno važno za pojedinca da njegovi pogledi, vjerovanja i osjećaji tvore za njega zbilju, više od onoga što mu govore njegovi

${ }_{32}$ Usp. John Street, Masovni mediji, politika i demokracija, Fakultet političkih znanosti Sveučilišta u Zagrebu, Zagreb 2003., str. 33.

33 Usp. isto.

${ }_{34}$ Usp. M. KUNCZIK - A. Zipfel, $n$. dj., str. 148.

35 Usp. D. ČEREPINKo, $n$. dj., str. 159. 
osjeti i razum. . ${ }_{36}$ Fromm tvrdi ${ }^{37}$ kako prosječni pojedinac sam sebi ne dopušta svjesnost svojih misli i osjećaja koji su nespojivi s obrascima njegove kulture, nego ih je prisiljen potiskivati. Struktura propagiranja današnjih vrijednosti $u$ kontekstu nužnosti brzine u svim životnim segmentima (brza hrana, brzo postizanje uspjeha, sve na brzinu) otvara prostor koji dopušta manipulaciju današnjim društvom koje se lako može prepoznati u bolesnome modernom društvu suočenu s fenomenom „urbane patologije“. ${ }^{38} \mathrm{Uz}$ taj, u kontekstu brzih postignuća pod okriljem medija ističe se i fenomen „poznat zbog poznatosti“, odnosno „slavna je osoba ona koja je poznata zbog svoje poznatosti““39, što, također, dolazi „preko noći“. Neprekidna brzina u svim životnim segmentima jednostavno ne ostavlja prostor za dublje promišljanje i dopiranje do istinske stvarnosti.

Izazovi s kojima se današnje informacijsko društvo susreće očituju se u velikome psihičkom opterećenju te se izlažu stvaranju paraliziranih koncepata i poredaka. ${ }^{40}$ Dolazi do pojave mnoštva interpretatora i interpretacija u kontekstu čovjekove potrage za nečim višim, za nekim načelima djelovanja koja se, ako su iskrena, mogu naći na prekretnici između dobitka i gubitka, između integracije u društvo i izbacivanja iz društva u koje je čovjek svojim postojanjem umetnut. $S$ jedne strane postoji velika količina povezanosti putem informacijsko-komunikacijskih tehnologija, koja djeluje na dostupnost informacija, povezanost sa svima i u svakome trenutku, a s druge strane javlja se društvena izolacija koja se očituje u individualiziranome pojedincu kojemu je danas dovoljna činjenica postojanja dostupnosti mreže i posjedovanja uređaja kojima kroz apsorbiranje medijskih sadržaja živi svoju stvarnost. Informatizaciju Bauer ${ }^{41}$ opisuje kao sredstvo kulturne samoreprodukcije i

36 Erich Fromm, S onu stranu okova iluzije, Naprijed, Zagreb, 1980., str. 111.

37 Usp. isto, str. 112.

${ }^{8}$ Usp. Zlatko Kramarić, Hrvatska politička laž ili neizvjesnost demokracije, Otokar Keršovani, Rijeka, 2005., str. 164.

39 HaJRUdin Hromadžıć, „Mediji i spektakularizacija društvenog svijeta. Masmedijska produkcija 'kulture slavnih", Filozofska istraživanja, Hrvatsko filozofsko društvo, Zagreb, god. XXX. (2010.) br. 4., str. 626.

40 Usp. T. A. Bauer, $n$. dj., str. 75.

${ }_{41}$ Usp. isto, str. 76. 
civilizirajućega razvitka. Opisuje je kao sredstvo kojim se postižu javna i privatna samoorganizacija društva. Pojmovi kao „informacijska autocesta“, „autocesta podataka“, „informacijsko društvo“, koji su dio elektroničkoga, točnije virtualnoga prostora koji ipak još uvijek nije ušao u prostor većega dijela svjetske populacije,$^{42}$ omogućuju prostor u okviru kojega se razvijaju središta moći i oligopolije koja su nekada prije bila razvijena $u$ nekim drugim prostorima. ${ }^{43}$ Današnje se društvo sve više pronalazi u nekim okvirima virtualno distribuirana društva i živi tako što se hrani medijski produciranim sadržajima pri čemu se smisao pronalazi u okvirima medijski zadanih normi. Problem je što isto to društvo postaje ugroženo vlastitom krhkošću. ${ }^{44}$ Nameće se medijski inscenirana stvarnost koja u sve većem obimu potiskuje stvarnost. Dolazi do stanja u kojem je medijski produciran sadržaj percipiran kao stvarnost, a stvarnost postaje fantomska. ${ }^{45}$ Izgleda da današnje demokratsko društvo ne uzima u obzir postojanje ogromne količine dobro uigranih mehanizama samozavaravanja na koja upućuje Chomsky, a koji vode do provođenja odluka krupnoga kapitala. ${ }^{46}$ Samozavaravanje je segment koji je bitno uočiti s obzirom na neprestano veličanje života u slobodi i demokraciji današnjega društva, dok se pri tome spominju prijašnji oblici neslobode, manipulacije i medijskih laži vezanih za neke ranije totalitarne režime.

Sve navedeno upućuje na činjenicu da je društvo danas, više nego ikada, ograničeno bez obzira na dostupnu neizmjernu količinu slobode i izbora. Renata Salecelto navedeno vrlo zorno opisuje na sljedeći način: „Životni izbor opisan je istim terminima kao i potrošački: u potrazi smo za 'pravim' životom isto kao što tražimo prave tapete ili regenerator za kosu. ${ }^{47} \mathrm{Na}$ prvu bi se mogućnost slobode izbora trebala činiti kao neki olakšavajući čimbenik, ali što se zapravo danas događa? Dolazi li danas više nego ikada do sukoba unutar samoga čovjeka između

\footnotetext{
${ }_{42} \quad$ Usp. isto, str. 78.

43 Usp. isto.

44 Usp. isto, str. 85.

45 Usp. GINTER ANDERs, Svet kao fantom i matrica: filozofska razmatranja o radiju i televiziji, Prometej, Novi Sad, 1996., str. 21. citurano prema S. Alić, n. dj., str. 112.

46 Usp. S. Alić, $n$. dj., str. 226.

47 Renata Salecl, Tiranija izbora, Fraktura, Zaprešić, 2012., str. 15.
} 
njegova stvarnog ja i propisanog (idealnog) ja? Police u knjižarama prepune su raznih priručnika za samopomoć, milijuni dolara troše se na prodaju i promidžbu antidepresiva, farmaceutske industrije financiraju brojna istraživanja i publikacije. ${ }^{48}$ Brojna istraživanja pokazuju kako depresija danas predstavlja ogroman problem. U skladu s podatcima Svjetske zdravstvene organizacije pretpostavljalo se da će oko 2020. godine depresija zauzeti drugo mjesto na ljestvici svjetskih zdravstvenih problema, ${ }^{49}$ a s obzirom na trenutačnu situaciju može se zaključiti da je navedeno bilo točno. Postavlja se pitanje zbog čega ljudi modernoga društva koji žive u dostupnosti gotovo svega nisu istinski zadovoljni i sretni te se depresija koju ocrtava opća dugoročna nezainteresiranost (ljudi nemaju volje gotovo ni za čim, čak niti za aktivnostima koje su ih ranije činile zadovoljnima, zaokupljeni su pesimističnim pogledima na budućnost, osjećaju bezvrijednost, ponekad i suicidalne ideje) ${ }^{50}$ javlja kao glavni problem današnjice. Ono što svakako treba istaknuti jest to da se depresija češće javlja kod ljudi s malo međuljudski bliskih odnosa. ${ }^{51}$ Stoga odgovor možda leži u činjenici da, iako je moderno društvo umreženo te ljudi putem različitih online komunikacijskih alata nisu gotovo nikada sami, zapravo doživljavaju samoću više nego ikada prije. Uz to, ljudi možda smatraju da žive iskreno i u skladu s vlastitim željama i izborima jer nisu osvijestili pojam „ispiranja mozgova“, koji podrazumijeva niz edukativno-propagandnih metoda i postupaka koji se od istih uobičajenih razlikuju po tome što ovi koji djeluju sa svrhom ispiranja mozgova ciljaju ne samo na to da primatelji poruke modificiraju i izmijene neke svoje stavove nego i da izmijene čitavu strukturu svoje ličnosti. ${ }^{52}$ Činjenica da je pojedincu prepušten izbor u kontekstu

${ }_{48}$ Usp. Rudolf Gregurek, „Psihoterapija depresija“, Medicus, Pliva Hrvatska, Zagreb, god. XIII. (2004.) br. 1., str. 95.

49 Usp. Ivan URLIĆ, „Depresija u 21. stoljeću - u povodu obilježavanja Europskog dana borbe protiv depresije“, MEDIX, C.T. - Poslovne informacije, Zagreb - Sarajevo, god. XIX. (2013.), br. 106., str. 174.

50 Usp. Dalibor Karlović, „Depresija: klinička obilježja i dijagnoza“, Medicus, Pliva Hrvatska, Zagreb, god. XXVI. (2017.) br. 2., str. 162.

${ }_{51} \quad$ Usp. isto, str. 162.

52 Usp. Mladen Zvonarević, Socijalna psihologija, Školska knjiga, Zagreb, 1978., str. 720. 
slobodne volje (A. Camus: „Da se ubijem ili da odem na kavu?“"53) može voditi do potrebe pronalaska nekoga autoriteta, kako ga Žižek u svome dokumentarnom filmu Pervertitov vodič kroz ideologiju naziva the big other. Možda je upravo propaganda opće slobode u svim životnim segmentima opterećujuća za čovjeka jer se nije u stanju sam nositi sa svim odlukama i izborima koje treba donijeti na dnevnoj bazi. Prema tomu može se zaključiti da je čovjeku potreban netko tko će odobriti njegov izbor, netko tko je iznad njega, jer čovjek sam nije dovoljno skladan i siguran u svoje djelovanje, razlučivanje dobra od zla, pravilna od nepravilna, istine od laži. Možda današnje društvo pokušava pronaći the big other ličnost kroz medijsku propagandu i nametnute vrijednosti te kroz negiranje tradicionalnoga. Iako sve navedeno u ovome radu upućuje na suprotno, zadnja opcija ne mora nužno biti loša ako tako društvo može postići istinski željenu razinu zadovoljstva i ispunjenosti.

\section{Zaključak}

Današnje je društvo društvo koje uz propagiranje ogromne količine slobodoumlja zapravo prikriveno zastupa veliku količinu obrazaca koji se nameću kao kult nekih novih, modernih nametnutih vrijednosti. Kao takvo pogodno je za manipuliranje i svojevrsno krojenje prema nacrtima centara moći. Razina povjerenja u vlastitu kulturu i ranije usađene vrijednosti kao da se neprestano smanjuje, ali potraga za nekom višom silom koja odobrava čovjekove postupke i način života ipak i dalje postoji. Navedeno se očituje u percipiranju oblikovanih informacija, bez težnje za stvaranjem vlastitoga konteksta i dubljega promišljanja. Dolazi do bezuvjetna prihvaćanja danih imperativa, bez uzimanja u obzir mogućnosti za postojanjem određenih granica kao osobnoga štita. Potreba za konstruiranjem vlastitoga identiteta i vlastitih vrijednosti trebala bi se nametnuti u postojanju svakoga pojedinca kao nešto čime će se voditi i čime će moći reagirati u kontekstu samoamputacije kada se za to pojavi potreba, točnije, potrebno je otvoriti mogućnosti za uočavanje nužnosti iste. Selektivan pristup, bez sagledavanja svih elemenata

$53 \quad$ R. SALECL, $n$. dj., str. 4 .o. 
vezanih za određenu situaciju i servirani sadržaj, nije u stanju polučiti toleranciju i prihvaćanje radi harmonizacije društva u kontekstu istinskoga prihvaćanja različitosti. Stoga se nameće nužnost propitivanja svih dostupnih sadržajnih segmenata, ali u kontekstu izazova. Pozitivno samoamputiranje u razmatranju informacijsko-komunikacijskoga društva kao izazova može pridonijeti novim pogledima koji će usmjeravati društvo u odabir pozitivnih stavki dostupna sadržaja i uzrokovati odbacivanje onih negativnih. Iz toga proizlazi da se nužnost sagledavanja šire slike, kreiranje vlastitih segmenata i uviđanja istine, koja će onda voditi do izbjegavanja manipulativnih utjecaja na društvo, treba osvijestiti kod svakoga pojedinca. Nije potrebno ići u krajnosti s apsolutnim negativizmom kada je riječ o medijski distribuiranim sadržajima, ali je potrebno osvijestiti da nitko ne bi trebao držati vlast nad pojedinčevim interpretacijama i promišljanjima koja su vezana za određeni sadržaj. U tome pravcu potrebno je neprestano tragati za stvarnim kontekstom distribuirana sadržaja u okviru kojega će svaki pojedinac biti sposoban razumjeti onoga koji je u istome prisutan, onoga koji ga je distribuirao te segmentiranim razmatranjem moći doći do objektivnih zaključaka prožetih subjektivnim iskustvom. Pojedinac medijske sadržaje na globalnoj razini ne može mijenjati, ali može mijenjati vlastiti pogled na uokvireni sadržaj putem strukturirana i promišljena sagledavanja činjenica te konzumiranja danih sadržaja s optimalnom količinom rezerve. I na kraju, potrebno je osvijestiti činjenicu da svaki pojedinac u današnjem modernom umreženom društvu može biti i recipijent i proizvođač informacija. U slučaju ove druge uloge, prije produciranja i distribuiranja vlastitih sadržaja, nikako se ne bi smjela zanemariti moralna i etička načela s obzirom na mogući utjecaj objavljenih sadržaja.

\section{Literatura}

- Alić, SEAd, Mediji, od zavodenja do manipuliranja, AGM, Zagreb, 2009.

- BARAKOvic, VedAdA, „Medijska konstrukcija ekstremnog vremena: Ključne riječi i metafore kao alati framinga“, Medijski dijalozi, 
časopis za istraživanje medija $i$ društva, Istraživački medijski centar - Podgorica, Podgorica, god. V. (2012.) br. 13. - 14., str. 507-515.

- Bauer Thomas A., Mediji za otvoreno društvo, Sveučilišna knjižara d.o.o., Zagreb, 2007.

- Čerepinko, Darijo, Komunikologija: Kratki pregled najvažnijih pojmova, teorija i principa, Veleučilište u Varaždinu, Varaždin, 2011.

- Fromm Erich, S onu stranu okova iluzije, Naprijed, Zagreb, 1980.

- Goffman ERvin, Frame analysis: An essay on the organization of experience, Harper \&Row, New York, 1974.

- Gregurek Rudolf, „Psihoterapija depresija“, Medicus, Pliva Hrvatska, Zagreb, god. XIII. (2004.) br. 1., str. 95-100.

- Hromadžıć HajRudin, „Mediji i spektakularizacija društvenog svijeta. Masmedijska produkcija 'kulture slavnih'“, Filozofska istraživanja, Hrvatsko filozofsko društvo, Zagreb, god. XXX. (2010.) br. 4., str. 617-627.

- Inglis Fred, Teorija medija, Barbat - AGM, Zagreb, 1997.

- Karlović Dalibor, „Depresija: klinička obilježja i dijagnoza“, Medicus, Pliva Hrvatska, Zagreb, god. XXVI. (2017.) br. 2., str. 161-165.

- Kramarić Zlatko, Hrvatska politička laž ili neizvjesnost demokracije, Otokar Keršovani, Rijeka, 2005.

- Kramarić Zlatko, Jesu li političari krivi za sve?, Naklada EOS, Osijek, 2003.

- Kolarek Ida - Milković Marin - Kosić Tomislav, „Dizajn i vizualni efekti koji induciraju iluziju kretanja“, Tehnički glasnik, Sveučilište Sjever, Varaždin, god. V. (2011.) br. 2, str. 80-88.

- Kunczik Michael - Astrid Zipfel, Uvod u znanost o medijima i komunikologiju, Zaklada Fridrich Ebert, Zagreb, 2006.

- Labaš Danijel - Mihovilović Maja, „Masovni mediji i semiotika popularne kulture“, Kroatologija, Hrvatski studiji Sveučilišta u Zagrebu, Zagreb, god. II. (2011.) br. 1., str. 95-122. 
- Lipovetsky Gilles, Paradoksalna sreća - ogled o hiperpotrošačkom društvu, Izdanja Antibarbarus, Zagreb, 2008.

- Mcluhan Marshall, Razumijevanje medija, Golden marketing - Tehnička knjiga, Zagreb, 2008.

- Naughton John, Od Gutenberga do Zuckerberga, Edicije Božićević, Zagreb, 2014.

- „NescafeGold“, (15. XII. 2015.), <https://www.youtube.com/watch?v=pvqkMsh_eZo\&ab_channel=PublicisRomania>, (30. I. 2021.)

- Salecl Renata, Tiranija izbora, Fraktura, Zaprešić, 2012.

- Street John, Masovni mediji, politika i demokracija, Fakultet političkih znanosti Sveučilišta u Zagrebu, Zagreb, 2003.

- URlić Ivan, „Depresija u 21. stoljeću - u povodu obilježavanja Europskog dana borbe protiv depresije“, MEDIX, C.T. - Poslovne informacije, Zagreb - Sarajevo, god. XIX. (2013.), br. 106., str. 174.

- Zvonarević Mladen, Socijalna psihologija, Školska knjiga, Zagreb, 1978. 
Review article

Received on February 7, 2021

Accepted on December 6, 2021

IVANA RAŠAN

University of Zagreb, Faculty of Electrical Engineering and Computing

\section{TODAY'S MEDIA CULTURE AND IMPOSED LIFE VALUES}

\section{Abstract}

The paper gives an overview of modern society and popular culture as a culture of imposed values, the influences that arise from it and the ways in which today's society, that lives in a kind of media forest, functions. It will also give an overview of how society functions in unlimited freedom of choice and observes today's value system, as well as the influences resulting from the media content consumed. The focus is on the individual and the question is raised as to whether, in today's information forest, the individual can muster the strength to look deeply at the information presented with the intention of various manipulative effects and separate it from that information which is disseminated as such for literal information. The paper presents the idea of today's modern society, which, on one hand, lives its life to the fullest in the accessibility of everything and surrounded by all, but, on the other hand, faces isolation and loneliness.

Keywords: modern society; media; individual; imposed values; framing 